\title{
Electrocatalysis of Hydrogen Evolution Reaction on Au(111) by Spontaneously Deposited Iridium in Acid Solution
}

\author{
Svetlana Štrbac, ${ }^{1, z}$ Irina Srejić, ${ }^{2}$ and Zlatko Rakočević ${ }^{2}$ \\ ${ }^{I}$ ICTM-Institute of Electrochemistry, University of Belgrade, 11000 Belgrade, Serbia \\ ${ }^{2}$ INS Vinča, Laboratory of Atomic Physics, University of Belgrade, 11001 Belgrade, Serbia
}

\begin{abstract}
Iridium nanoislands are spontaneously deposited on $\mathrm{Au}(111)$ from $\left(1 \mathrm{mM} \mathrm{IrCl} \mathrm{m}_{3} \cdot \mathrm{xH}_{2} \mathrm{O}+0.5 \mathrm{M} \mathrm{H}_{2} \mathrm{SO}_{4}\right)$ depositing solution. Atomic Force Microscopy images of the obtained Ir/Au(111) bimetallic surfaces show that gold surface is fully covered with nanosized Ir islands after only $3 \mathrm{~min}$ of deposition. X-Ray Photoelectron Spectroscopy analysis shows that the deposit consists of a mixture of adsorbed hydrated $\mathrm{IrCl}_{3}$ and to a lesser extent of $\mathrm{Ir}(\mathrm{OH})_{3}$. Cyclic Voltammetry characterization in $0.5 \mathrm{M} \mathrm{H}_{2} \mathrm{SO}_{4}$ solution does not show clear Hupd region prior to hydrogen evolution reaction (HER). Linear Sweep Voltammetry measurements show pronounced catalysis of HER on Ir modified Au(111) surface compared to bare Au(111). With prolonged Ir deposition, the observed limited increasing activity for HER of Ir/Au(111) surfaces is in accordance with the limited Ir/Au(111) surface morphology changes.

(C) The Author(s) 2018. Published by ECS. This is an open access article distributed under the terms of the Creative Commons Attribution 4.0 License (CC BY, http://creativecommons.org/licenses/by/4.0/), which permits unrestricted reuse of the work in any medium, provided the original work is properly cited. [DOI: $10.1149 / 2.0441815 \mathrm{jes}]$

(cc) BY
\end{abstract}

Manuscript submitted July 29, 2018; revised manuscript received October 31, 2018. Published November 14, 2018. This paper is part of the JES Focus Issue on Electrocatalysis — In Honor of Radoslav Adzic.

Hydrogen evolution reaction (HER) is one of the most important reactions in electrocatalysis. This is primarily due to the role of HER in hydrogen production during water electrolysis. Furthermore, HER is the main cathodic reaction in proton-exchange membrane fuel cells, as well as during methanol oxidation in alcohol fuel cells. It is also the simplest reaction, and proceeds in two steps with adsorbed hydrogen as the only intermediate. In acid media the first step is always Volmer reaction. It assumes the discharge of a proton which produces the adsorbed hydrogen as the intermediate. In the second step molecular hydrogen is formed on the surface either through Tafel reaction, in which the recombination of two adsorbed hydrogen atoms takes place, or through Heyrovski reaction in which adsorbed hydrogen atom reacts with a second proton. Thus, hydrogen evolution occurs through either Volmer-Tafel or Volmer-Heyrowski or through a dual reaction path.

HER generaly occurs at heigher overpotentials, which needs to be lowered using the most active cathode materials for efficient electrocatalysis. With respect to the overpotential, platinum group metals ( $\mathrm{Ru}, \mathrm{Rh}, \mathrm{Pd}, \mathrm{Os}$, Ir, and Pt) have shown to be the best electrode material for HER due to their unique physical and chemical properties. Plot of the exchange current density versus the strength of the metalhydrogen bond formed during electrochemical reaction known as a Volcano plot has shown that Pt is the best catalyst for HER in acid solution. ${ }^{1}$ This plot was recently challenged when oxide covered metals were excluded, ${ }^{2}$ and the hydrogen adsorption energy calculated by density functional theory were taken instead of the streanght of metal hydride bond. ${ }^{3}$ It was proved that Pt remained the best catalyst for HER, followed by Pd, Rh, and Ir, while the activity of Au is still rather poor. One of the ways to improve the activity of gold for HER in acid solution is its modification by a submonolayer to monolayer amount of a foreign noble metal (Me), forming $\mathrm{Me} / \mathrm{Au}$ bimetallic electrodes with unique morphological and catalytic properties. ${ }^{4-10}$ Since gold is rather inert for HER, the main contribution to the activity of Me/Au bimetallic surfaces comes from a foreign metal. However, Au support does contribute indirectly through the strong electronic interaction with the deposited foreign metal. With respect to surface morphology, $\mathrm{Au}$ single crystals are convenient as substrate electrode because of their well-defined surface structure, which enables the formation of equally well-defined $\mathrm{Me} / \mathrm{Au}$ bimetallic surface structure. HER has been widely studied on Pd overlayers deposited on different Au single crystals and it was shown that the electronic effect induced between

${ }^{\mathrm{z} E-m a i l: ~ s s t r b a c @ t m f . b g . a c . r s ~}$
Pd deposit and Au substrate can be tuned by means of different deposition methods and different Pd coverage to achieve higher activity for HER.$^{5-7}$ Significant improvement of the electrocatalytic activity of $\mathrm{Au}(111)$ with Rh overlayer was first predicted theoretically ${ }^{8,9}$ and confirmed experimentally. ${ }^{10}$ These studies have yielded significant results, showing that $\mathrm{Rh} / \mathrm{Au}(111)$ electrodes prepared by the facile and fast spontaneous deposition method are highly active for this reaction. ${ }^{10}$ High activity of $\mathrm{Rh} / \mathrm{Au}(111)$ system for HER was explained by the strong electronic effect induced between $\mathrm{Au}(111)$ substrate and $\mathrm{Rh}$ nanoislands, which facilitated different steps in HER mechanism and thus improved the overall reaction rate. Indeed, this electronic interaction has been experimentally proven by X-Ray Photoelectron Spectroscopy (XPS) technique. ${ }^{11}$ Structural sensitivity of bimetallic electrodes consisting of $\mathrm{Rh} / \mathrm{Au}(111)$ and $\mathrm{Rh} / \mathrm{Au}(100)$ for HER activity was recently reported. ${ }^{12}$

Ir as another noble metal exhibits unique chemical and physical properties. These include stability against various chemical reactions: resistance to corrosion, oxidation and dissolution. As a result of this it might be considered as a good candidate for a broad range of applications in electrochemistry. Therefore, both bare iridium and $\mathrm{Ir}$ based electrodes have found an incresing interest in electrocatalysis. Metallic Ir has shown good activity for hydrogen evolution, with the reaction mechanism similar to that on $\mathrm{Rh}$, but rather different than on $\mathrm{Au}$ and $\mathrm{Pt} .{ }^{13}$ Mechanism of hydrogen evolution on bimetallic $\mathrm{Rh} / \mathrm{Au}(111)$ compared to $\mathrm{Au}(111)$ and $\mathrm{Pt}(111)$ in sulfuric acid solution was reported in our previous work. ${ }^{10}$ It was recently reported that underpotential deposition of hydrogen (Hupd) takes place prior to hydrogen evolution on $\operatorname{Ir}(111)$ single crystal, ${ }^{14}$ polycrystalline $\mathrm{Ir}$ $(\operatorname{Ir}($ poly $)),{ }^{15}$ and on glassy carbon (GC) supported Ir nanostructures where Ir was also in metallic state. ${ }^{16,17}$ In all these cases, anodically grown Ir oxide is fully reduced at lower potentials. ${ }^{14,16}$ In contrast to this, on commercial $\mathrm{Ir} / \mathrm{GC},{ }^{18}$ instead of Hupd peaks only a broad potential region with no defined peaks was observed, indicating that Ir was not completely in the metallic state, but partly oxidized. A similar example was shown in Ref. 19, where Ir oxide was activated by termal treatment. Although such IrOx anodic films form non-conductive $\mathrm{Ir}_{2} \mathrm{O}_{3}$ at cathodic potentials prior to hydrogen evolution, that are never fully reduced, ${ }^{20,21}$ they are still very active for HER.

Ir was also used as a foreign deposit to modify metal electrodes using various deposition techniques, including spontaneous deposition, which is explored in this work. General advantage of spontaneous deposition method is very low consumption of otherwise expensive Pt group metal salts. The method is simple and enables control of the 
nature and amount of the deposited material by a proper choice of the counter anion, base solution and deposition time.

Ir was deposited spontaneously on $\mathrm{Ni}$ from acid solution using $\mathrm{IrCl}_{3}$ and/or $\mathrm{H}_{2} \mathrm{IrCl}_{6}$ as depositing salts. ${ }^{22-24}$ It was shown that during spontaneous deposition apart from IrClx and IrOx, a certain amount of metallic Ir is also deposited. Depending on the composition of Ir deposit, in some cases rather featureless cyclic voltammograms (CV) of Ir-modified Ni electrode in the potential region prior to hydrogen evolution are obtained. ${ }^{22,23}$ In contrast to this, it was shown that during spontaneous deposition of $\mathrm{Ir}$ on $\mathrm{Ni}$ from the solution containing $\mathrm{IrCl}_{3} \cdot \mathrm{xH}_{2} \mathrm{O}$ salt dissolved in $\mathrm{HCl}, \mathrm{Ni}$ is oxidized to $\mathrm{Ni}^{2+}$, while $\mathrm{Ir}^{\mathrm{z}}$ is reduced to metal, ${ }^{24}$ which is confirmed by the appearance of Hupd region on $\mathrm{CV}$ s characteristic of bare $\mathrm{Ir}^{25}$

In this work, spontaneous deposition of Ir on the $\mathrm{Au}(111)$ surface was performed using $\left(1 \mathrm{mM} \mathrm{IrCl} 3 \cdot \mathrm{xH}_{2} \mathrm{O}+0.5 \mathrm{M} \mathrm{H}_{2} \mathrm{SO}_{4}\right)$ as the depositing solution. Obtained bimetallic Ir/Au(111) electrodes were characterized by Atomic Force Microscopy (AFM), X-ray Photoelectron Spectroscopy and Cyclic Voltammetry. The activity of such bimetallic electrodes toward hydrogen evolution was investigated in $0.5 \mathrm{M} \mathrm{H}_{2} \mathrm{SO}_{4}$ solution using Linear Sweep Voltammetry (LSV).

\section{Experimental}

$\mathrm{Au}(111)$ single crystal, $12 \mathrm{~mm}$ in diameter and $1.13 \mathrm{~cm}^{2}$ geometric area (MaTeck, Julich, Germany) was used as a substrate electrode for the deposition of iridium. Before each measurement, $\mathrm{Au}(111)$ electrode was prepared by electrochemical polishing and annealing in butane flame. After each measurement the deposited Ir was removed electrochemically and then the clean $\mathrm{Au}(111)$ substrate was annealed again.

Spontaneous deposition of Ir was performed by the immersion of the $\mathrm{Au}(111)$ single crystal electrode at an open circuit potential (OCP) into $\left(1 \mathrm{mM} \mathrm{IrCl} 3 \cdot \mathrm{xH}_{2} \mathrm{O}+0.5 \mathrm{M} \mathrm{H}_{2} \mathrm{SO}_{4}\right)$ solution for the durations of 3, 30 and $60 \mathrm{~min}$ (further on referred to as the deposition time). It is known that when Ir(III) chloride hydrate is dissolved in acid solution numerous complexes are formed and that their composition depends strongly on their concentration, $\mathrm{pH}$ of the solution, aging time, and temperature as can be found in Ref. 26 and references therein. Briefly, among various complexes, those of $\operatorname{Ir}(\mathrm{III})$ and $\operatorname{Ir}(\mathrm{IV})$ appear as numerous chloroaquo species with a general formula $\left[\operatorname{Ir}\left(\mathrm{H}_{2} 0\right)_{6-n} \mathrm{Cl}_{n}\right]^{(3-n)}$, where $\mathrm{n}$ is $3,4,5$ and 6 , and of $\operatorname{Ir}(\mathrm{IV})\left[\operatorname{Ir}\left(\mathrm{H}_{2} 0\right)_{6-\mathrm{n}} \mathrm{Cl}_{\mathrm{n}}\right]^{(4-\mathrm{n})}$, where $\mathrm{n}$ is 3 , 4,5 and 6 , respectively. The solution containing predominantly $\operatorname{Ir}(\mathrm{III})$ chloro complexes show yellow-green colors, while dilute acid solutions of Ir(IV) chloro complexes show various red, orange and yellow colors. Since the Ir depositing solution used in this work shows predominantly yellow color, it is assumed that it contains both Ir(III) and Ir(IV) complexes, in the redox equilibrium:

$2\left[\operatorname{Ir}\left(\mathrm{H}_{2} 0\right)_{6-n} \mathrm{Cl}_{\mathrm{n}}\right]^{(4-\mathrm{n})}+\mathrm{H}_{2} \mathrm{O} \leftrightarrow 2\left[\operatorname{Ir}\left(\mathrm{H}_{2} \mathrm{O}\right)_{6-\mathrm{n}} \mathrm{Cl}_{\mathrm{n}}\right]^{(3-\mathrm{n})}+1 / 2 \mathrm{O}_{2}+2 \mathrm{H}^{+}$

Accordingly, upon immersion of the gold electrode into the solution containing different Ir complexes, the spontaneous deposition process occurs, which causes the change of the OCP over time. OCP changes are measured by chronopotentiometry starting from the immersion of $\mathrm{Au}(111)$ electrode into the depositing solution. For comparison, chronopotentiometry curves for $\mathrm{Au}(111)$ and for bare Ir wire in the base $0.5 \mathrm{M} \mathrm{H}_{2} \mathrm{SO}_{4}$ solution were also recorded.

Multimode Quadrex SPM (Veeco Instruments, Inc.) was explored for the observation of the main surface properties of the as prepared Ir/Au(111) electrodes. Ex situ imaging was performed by tapping mode AFM using a silicon probe (Tip-Vista probe, T190R-25, $190 \mathrm{kHz}$ contilever with tip radius lower than $10 \mathrm{~nm}$ ). Height and phase AFM images were recorded simultaneously which enabled direct comparison of the surface topography observed from height images, and the deposit coverage obtained from phase images. Deposit domains were highlighted on phase images due to their sensitivity on the chemical differences between the deposit and substrate. This gives as a result mapping the surface chemistry from which surface cover- age can be estimated as the fraction of the substrate surface covered with the deposit.

XPS spectra of $\operatorname{Ir} / \mathrm{Au}(111)$ bimetallic electrode obtained after $30 \mathrm{~min}$ Ir deposition were taken immediately after the electrode was prepared and rinsed with water. XPS analysis was carried out using SPECS System with XP50M X-ray source for Focus 500 and PHOIBOS $100 / 150$ analyzer. AlK $\alpha$ source $(1486.74 \mathrm{eV})$ at a $12.5 \mathrm{kV}$ and $32 \mathrm{~mA}$ was used for this study. XPS spectra were obtained at pressures in the range of $3 \times 10^{-8}-2 \times 10^{-9} \mathrm{mbar}$. Survey spectra were recorded from $0-1000 \mathrm{eV}$, with the energy step of $0.2 \mathrm{eV}$, dwell time of $0.5 \mathrm{~s}$, and pass energy of $40 \mathrm{eV}$ in the Fixed Analyzer Transmission (FAT) mode. High resolution region spectra for $\mathrm{Au} 4 \mathrm{f}, \mathrm{Au} 4 \mathrm{~d}$, Ir 4f, and $\mathrm{O}$ $1 \mathrm{~s}$ were recorded with the energy step of $0.1 \mathrm{eV}$, dwell time $2.0 \mathrm{~s}$ and pass energy of $40 \mathrm{eV}$ in the FAT mode. Due to the very low intensity, high resolution spectra for Ir $4 \mathrm{f}$ included 10 collected scans. Spectra were collected by SpecsLab data analysis software and analyzed by CasaXPS software package, both supplied by the manufacturer.

Electrochemical measurements were performed in the conventional three electrode cell connected to a Pine Instrument bipotentiostat AFCBP1, where $\operatorname{Ir} / \mathrm{Au}(111)$, bare $\mathrm{Au}(111)$ and $\operatorname{Ir}($ poly) were used as working electrode, platinum wire as a counter and $\mathrm{Ag} / \mathrm{AgCl}$, $3 \mathrm{M} \mathrm{KCl}$ as a reference electrode. All electrochemical measurements were performed in $0.5 \mathrm{M} \mathrm{H}_{2} \mathrm{SO}_{4}$ solution, deaerated by $99.999 \% \mathrm{~N}_{2}$ (Messer) using hanging meniscus method. The electrochemical characterization of Ir/Au(111) surfaces was performed by Cyclic Voltammetry in the potential region from $-0.18 \mathrm{~V}$ up to $0.95 \mathrm{~V}$ after conditioning at $0.15 \mathrm{~V}$ for $15 \mathrm{~min}$ in order to stabilize iridium deposit. Hydrogen evolution reaction was investigated by Linear Sweep Voltammetry (LSV) in the potential region from $0.0 \mathrm{~V}$ down to $-0.5 \mathrm{~V}$. LSV curves were recorded while scanning in cathodic direction after conditioning.

Stability of the deposited Ir species was challenged after $\mathrm{Ir} / \mathrm{Au}(111)$ electrode was subjected to sonication without holding the potential. Immediately after spontaneous deposition and rinsing with water, the electrode was immersed into the baker containing Millipure water, which was then sonicated for $5 \mathrm{~min}$. In the next step, the electrode was transferred into the cell and CV (or LSV) was recorded with the previous holding the potential at $0.15 \mathrm{~V}$ for $15 \mathrm{~min}$. The results were identical as the ones obtained without previous sonication, which indicated that Ir species were not loosely but tightly bound to the $\mathrm{Au}(111)$ surface, and not disturbed by sonication.

For comparison with the basic electrochemical measurements of Ir modified $\mathrm{Au}(111)$ electrode, Ir wire (MaTech, Jülich, Germany), $\operatorname{Ir}$ (poly), immersed into the solution was also used as working electrode (calculated geommetric area of the immersed wire was $0.8 \mathrm{~cm}^{2}$ ).

Solutions were prepared using $\mathrm{IrCl}_{3} \cdot \mathrm{xH}_{2} \mathrm{O}$ (MaTech, Jülich, Germany), suprapure $\mathrm{H}_{2} \mathrm{SO}_{4}$ (Merck), and Milli-pure water. All measurements were performed at room temperature. For the comparison with the results of bimetallic surfaces and $\mathrm{Au}(111)$ single crystal, Ir wire was used to obtain the CV and LSV data of bare iridium.

\section{Results and Discussion}

Spontaneous deposition of Ir on the Au(111) surface.-After immersion of the $\mathrm{Au}(111)$ single crystal electrode into the depositing ( $1 \mathrm{mM} \mathrm{IrCl} 3 \cdot \mathrm{xH}_{2} \mathrm{O}+0.5 \mathrm{M} \mathrm{H}_{2} \mathrm{SO}_{4}$ ) solution at the open circuit potential (OCP), the spontaneous deposition of Ir occurs, which can be followed by the changes of the OCP value over time. Chronopotentiometry curves, recorded over 60 minutes, for Ir deposition on $\mathrm{Au}(111)$ substrate, as well as curves for bare $\mathrm{Au}(111)$ electrode and Ir wire immersed into carrying $0.5 \mathrm{M} \mathrm{H}_{2} \mathrm{SO}_{4}$ solution, are given in Fig. 1. Immediately after immersion of $\mathrm{Au}(111)$ electrode into the depositing solution, the value of the OCP becomes higher than the OCP of $\mathrm{Au}(111)$ immersed only in the carrying solution, but still smaller than the OCP for Ir wire. During the first ten minutes, the OCP value increases sharply indicating fast deposition process, and then continues to rise only slightly toward more positive values, meaning that the deposition rate decreases until steady state is reached after 55 min. This can be seen as a plateau on the OCP curve, with the constant 


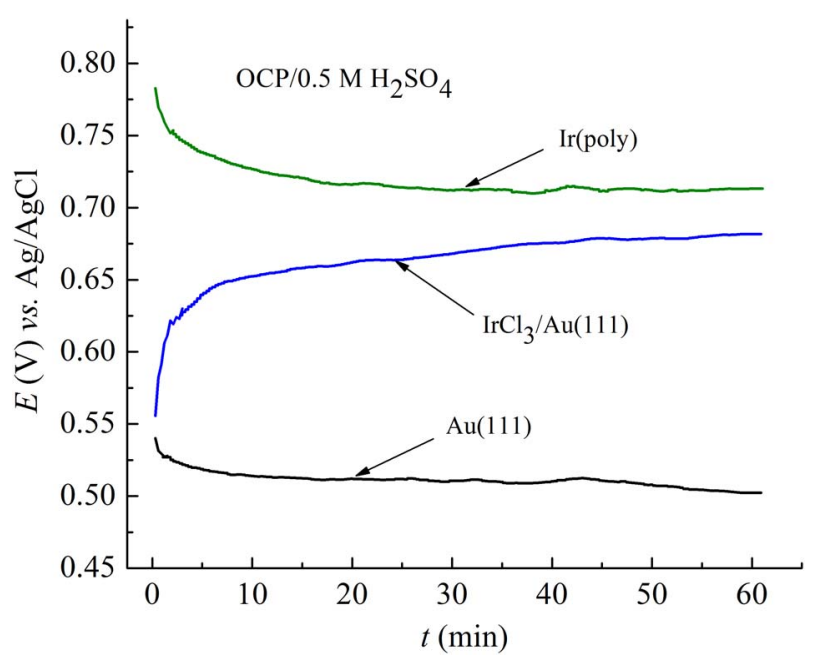

Figure 1. Chronopotentiometry curves showing the OCP changes during spontaneous deposition of $\mathrm{Ir}$ on the $\mathrm{Au}(111)$ from $1 \mathrm{mM} \mathrm{IrCl}_{3} \cdot \mathrm{xH}_{2} \mathrm{O}+0.5 \mathrm{M}$ $\mathrm{H}_{2} \mathrm{SO}_{4}$ solution, and during immersion of the $\mathrm{Au}(111)$ electrode and $\mathrm{Ir}($ poly) into the base $0.5 \mathrm{M} \mathrm{H}_{2} \mathrm{SO}_{4}$ solution.

OCP value of $0.68 \mathrm{~V}$. This value of the OCP obtained for $\mathrm{Ir} / \mathrm{Au}(111)$ system is much higher than the one for bare gold electrode of $0.51 \mathrm{~V}$, and approaches the OCP for bare Ir of $0.71 \mathrm{~V}$.

According to Ref. 26, the aqueous $\mathrm{IrCl}_{3} \cdot \mathrm{xH}_{2} \mathrm{O}$ solution contains both $\operatorname{Ir}(\mathrm{III})$ and $\operatorname{Ir}(\mathrm{IV})$ complexes (see the Experimental section). A comprehensive analyses in Ref. 23 has shown that depositing solutions consisting of $\mathrm{IrCl}_{3} \times \mathrm{xH}_{2} \mathrm{O}$ dissolved in $\mathrm{HCl}$ contain either a mixture of $\operatorname{Ir}\left(\mathrm{H}_{2} \mathrm{O}\right)_{3} \mathrm{Cl}_{3}$ and $\left[\operatorname{Ir}(\mathrm{OH})_{6}\right]^{3-}$, or a mixture of $\left[\mathrm{IrCl}_{6}\right]^{2-},\left[\mathrm{IrCl}_{6}\right]^{3-}$ and $\left[\operatorname{Ir}(\mathrm{OH})_{6}\right]^{2-}$, where iridium hydroxide is formed in the reaction:

$$
\left[\mathrm{IrCl}_{6}\right]^{3-}+6 \mathrm{H}_{2} \mathrm{O} \leftrightarrow\left[\operatorname{Ir}(\mathrm{OH})_{6}\right]^{3-}+6 \mathrm{HCl}
$$

When Ir was spontaneously deposited on $\mathrm{Ni}$ electrode from such solutions, it was shown that iridium deposits consisted of adsorbed Ir complexes, which became at least partly reduced up to metallic Ir, while Ni became oxidized. ${ }^{23,24}$

It will be shown below that when the $\mathrm{Au}(111)$ electrode is immersed into the similar $\left(1 \mathrm{mM} \mathrm{IrCl}_{3} \cdot \mathrm{xH}_{2} \mathrm{O}+0.5 \mathrm{M} \mathrm{H}_{2} \mathrm{SO}_{4}\right)$ depositing solution, its oxidation state does not change, but remains metallic. Therefore, gold is not a source of electrons for the reduction of Ir complexes like in the case of Ni in Refs. 23 and 24. The oxidation state of the deposited Ir and the nature of the deposited Ir complexes will be further evaluated by XPS measurements.

AFM images of Ir/Au(111) surface.-AFM images of the $\mathrm{Au}(111)$ substrate surface, the same one that was used in this work were presented in Ref. 11. It was shown that $\mathrm{Au}(111)$ surface consists of $100 \mathrm{~nm}$ up to $500 \mathrm{~nm}$ wide terraces separated mostly by monolayer (ML) high steps, although multilayer high steps can be frequently observed (the distance between two monolayers for $\mathrm{Au}(111)$ single crystal is $0.24 \mathrm{~nm}$ ). Height and phase AFM images of $\mathrm{Ir} / \mathrm{Au}(111)$ electrode surface obtained after 3 min Ir deposition are presented in Fig. 2. Surface topography image, Fig. 2a, reveal an interesting Ir/Au(111) nanostructure, with the Au(111) substrate surface almost fully covered with the deposited Ir islands. Cross-section along the line indicated in the image, Fig. 2b, shows that the height of individual or agglomerated Ir islands ranged from $0.25-1.0 \mathrm{~nm}$, meaning that the deposited islands are one to four monolayer high. In simultaneously recorded phase AFM image, Fig. 2c, where surface features are independent of surface topography, the boundaries of the deposited Ir islands are highlighted, and from the cross-section analysis, Fig. 2d, it can be estimated that the lateral size of the deposited Ir islands ranged from $10-25 \mathrm{~nm}$. When the phase lag, or threshold is set at $-5^{0}$, the contribution of the gold substrate is subtracted and in the new phase image, Fig. 2e, the part of the gold surface that is not covered with the deposit can be seen as the blue background, while the chemical contrast between Ir deposit and the gold substrate becomes clearly visible. This enabled quite accurate estimation of the overall coverage representing a percentage of the $\mathrm{Au}(111)$ surface covered with the deposited Ir islands. Quite high coverage of $(93 \pm 2) \%$ means that a maximum coverage equial to the full Ir overlayer is achieved already after 3 min Ir deposition. From the cross section from Fig. 2f, the average lateral size of agglomerated as well as individual Ir islands can be clearly estimated. $15 \%$ of Ir islands higher than the monolayer.

For longer deposition time of $30 \mathrm{~min}$ (not presented), the height of the deposited Ir islands is in the same height range as in the previous case, although with a higher fraction of higher islands (approx. 50\%). Lateral size range from $25-50 \mathrm{~nm}$, meaning that islands are much larger than in the previous case, although the estimated total coverage of $(93 \pm 2) \%$ is the same.

The presence of the deposited Ir islands contributes to the increase of surface roughness with respect to bare $\mathrm{Au}(111)$ surface, which can be determined from surface topography images. The average surface roughness increased from 0.1 for $\mathrm{Au}(111)$ surface to 0.8 for $93 \%$ $\mathrm{Ir} / \mathrm{Au}(111)$ obtained after $3 \mathrm{~min}$ Ir deposition. For Ir/Au(111) obtained after $30 \mathrm{~min}$ Ir deposition, the average roughness of 0.6 indicates a flattening effect with the increase of the lateral size of the deposited Ir islands. It is worth mentioning that in the case of $\mathrm{Rh}$ spontaneously deposited on the $\mathrm{Au}(111)$, the average roughness of $90 \% \mathrm{Rh} / \mathrm{Au}(111)$ is $0.4,{ }^{11}$ which is much lower than in the case of the deposited Ir.

XPS spectra of Ir/Au(111) surface.-Survey spectra of $\operatorname{Ir} / \mathrm{Au}(111)$ presented in Fig. 3, shows the positions of the main peaks characteristic for gold and iridium, as the main constituents of the bimetallic electrode. These peaks are: $\mathrm{Au} 4 \mathrm{f}$ and $\mathrm{Au} 4 \mathrm{~d}$, originating from $\mathrm{Au}(111)$ substrate, as well as Ir $4 \mathrm{f}$ and Ir $4 \mathrm{~d}$, originating from the deposited Ir. Besides, also identified are the following photoelectron lines: $\mathrm{O} 1 \mathrm{~s}$, $\mathrm{C} 1 \mathrm{~s}$, and $\mathrm{Cl} 2 \mathrm{~s}, \mathrm{Cl} 2 \mathrm{p}$, which according to their position correspond to adsorbed oxygen, carbon contaminant, and chloride originating as counter anion from the depositing Ir salt, respectively.

The positions of the main photoelectron lines corresponding to the metallic state of gold are found to be: $84.5 \mathrm{eV}$ and $88.0 \mathrm{eV}$, for $\mathrm{Au} 4 \mathrm{f}_{7 / 2}$ and $4 \mathrm{f}_{5 / 2}$, respectively, and $335.3 \mathrm{eV}$ and $353.2 \mathrm{eV}$, for $\mathrm{Au} 4 \mathrm{~d}_{5 / 2}$ and $4 \mathrm{~d}_{3 / 2}$, respectively for sputtered gold. ${ }^{27}$ Similarly, for bare $\mathrm{Au}(111)$ single crystal, the $4 \mathrm{f}_{7 / 2}$ bulk binding energy was determined to be $84.0 \mathrm{eV}$ in Refs. 28 and 29, and 84.4 eV in Ref. 11. High resolution spectra of $\mathrm{Au} 4 \mathrm{f}$ and $\mathrm{Au} 4 \mathrm{~d}$ doublets for $\mathrm{Au}(111)$ surface covered with Ir are presented in Fig. 4, where the positions of all the main photoelectron lines can be determined precisely and compared to the ones obtained in Refs. 11,27-29.

High resolution spectra of $\mathrm{Au} 4 \mathrm{f}$ doublet, consisting of $4 \mathrm{f}_{7 / 2}$ and $4 \mathrm{f}_{5 / 2}$ photoelectron lines are presented in Fig. $4 \mathrm{a}$. It was reported that in the case of bare $\mathrm{Au}(111)$, both $4 \mathrm{f}_{7 / 2}$ and $4 \mathrm{f}_{5 / 2}$ photoelectron lines are fitted to two components, one bulk and the other one surface component. ${ }^{11,29}$ In contrast to this, when $\mathrm{Au}(111)$ surface is covered with Ir overlayer, both lines are fitted with only one bulk component. Photoelectron line $\mathrm{Au} 4 \mathrm{f}_{7 / 2}$ is fitted to one component at $84.5 \mathrm{eV}$, corresponding to the bulk component for bare $\mathrm{Au}(111)$ at $84.4 \mathrm{eV},{ }^{11}$ although slightly shifted compared to the one at $84.0 \mathrm{eV}$ in Ref. 29, but still corresponding to the metallic state of gold. Photoelectron line $\mathrm{Au}$ $4 \mathrm{f}_{5 / 2}$ is also fitted with one component at $88.16 \mathrm{eV}$, which is slightly shifted compared to the one at $87.6 \mathrm{eV}$ in Ref. 29, but corresponds to the one at $88.07 \mathrm{eV}$ of bare $\mathrm{Au}(111)$ cystal, the same one as used in this work. ${ }^{11}$ This means that the surface component is supressed due to the interaction with the deposited Ir. The same supression of surface component was found for Se adsorbed on $\mathrm{Au}(111),{ }^{27}$ while in the case of $\mathrm{Rh}$ spontaneously deposited on $\mathrm{Au}(111)$, the surface component is shifted and only partly supressed. ${ }^{28}$

High resolution spectra of $\mathrm{Au} 4 \mathrm{~d}$ doublet, consisting of $4 \mathrm{~d}_{5 / 2}$ and $4 d_{3 / 2}$ photoelectron lines are presented in Fig. $4 \mathrm{~b}$. Both lines are fitted to one component each, whose binding energies are $335.8 \mathrm{eV}$ and $353.9 \mathrm{eV}$, for $4 \mathrm{~d}_{5 / 2}$ and $4 \mathrm{~d}_{3 / 2}$, respectively. This is in close agreement with the ones found for the metallic state of gold, ${ }^{27}$ but shifted for 


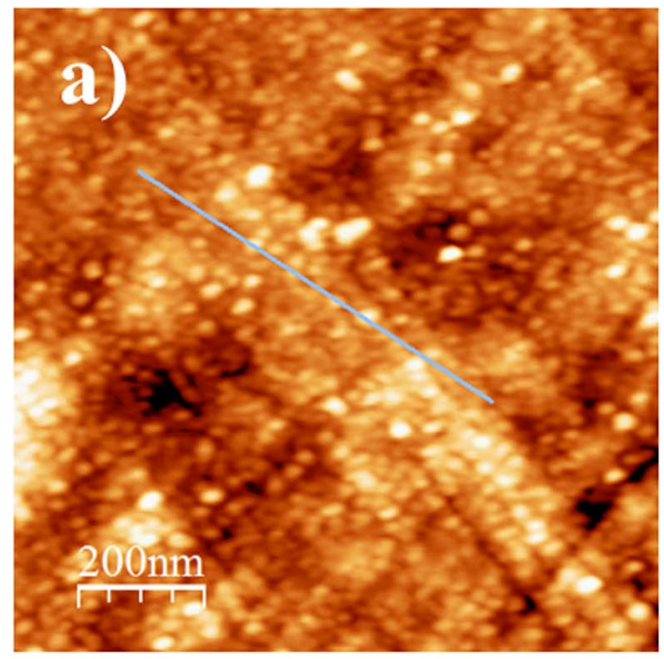

b)
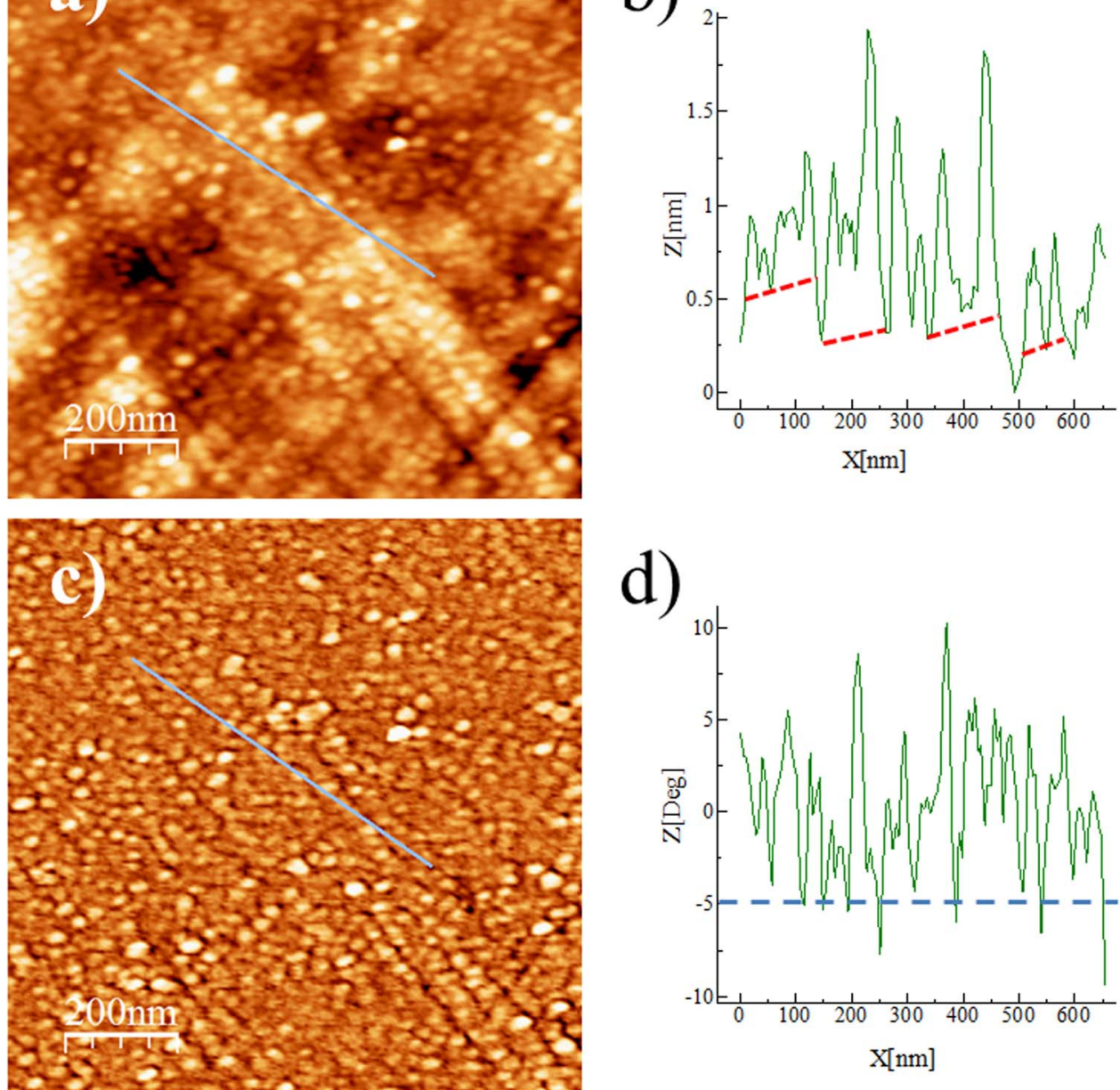

d)
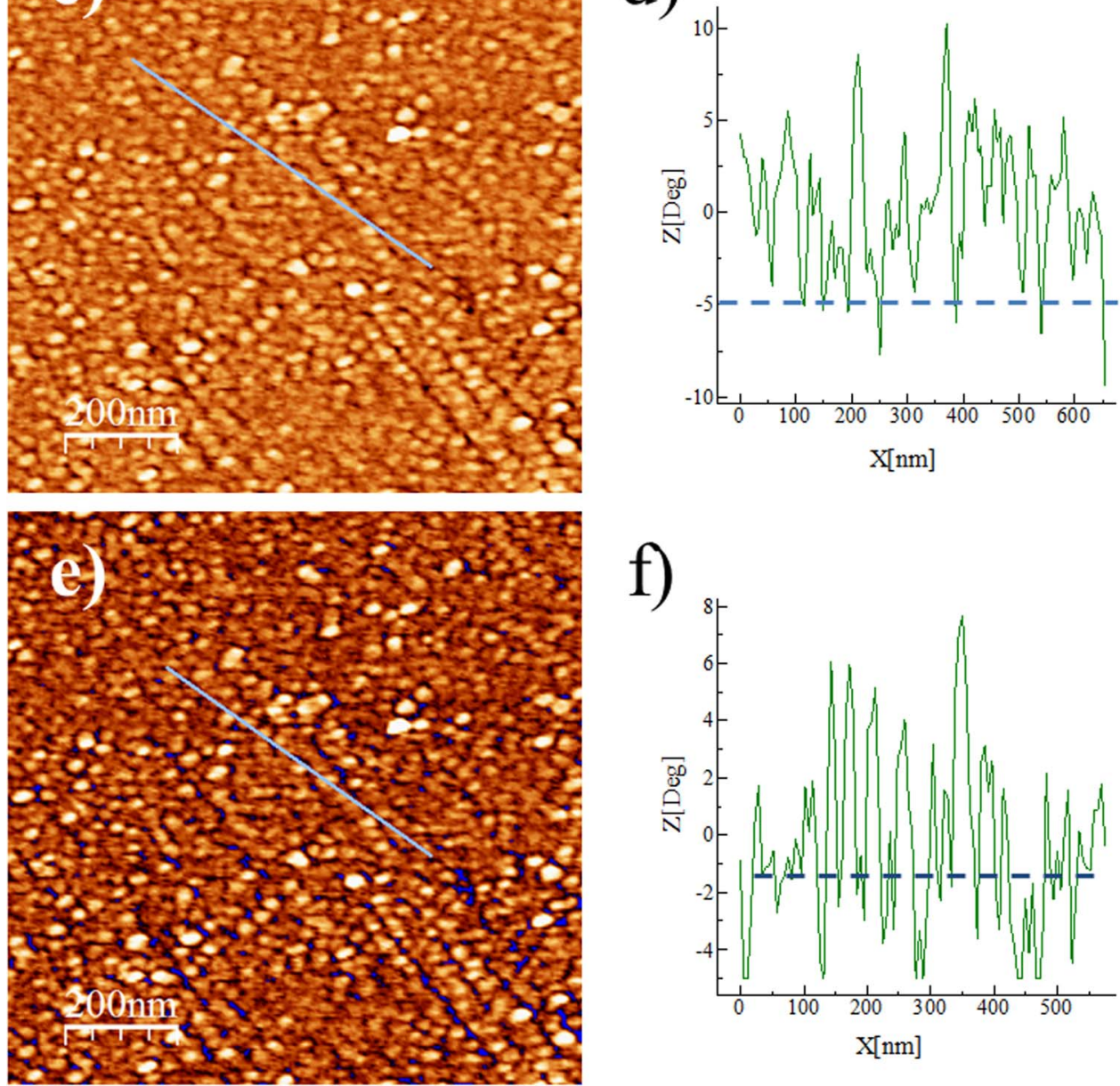

Figure 2. AFM images $(1 \times 1) \mu \mathrm{m}^{2}$ of $\operatorname{Ir} / \mathrm{Au}(111)$ bimetallic surface obtained after 3 min Ir deposition, showing: a) surface topography (z-range $\left.4.1 \mathrm{~nm}\right)$; b) cross-section along the line indicated in the image; c) and d) simultaneously recorded phase image z-range $21.7^{\circ}$ and corresponding cross-section; e) the same phase image obtained after the phase lag was cut at $-5^{\circ}$ (z-range $\left.16.7^{\circ}\right)$ showing $(93 \pm 2) \%$ Ir coverage; f) corresponding cross-section along the line indicated in the image.

approx. $0.6 \mathrm{eV}$, which can be ascribed to the interaction with the deposited Ir.

High resolution spectra of $\mathrm{Ir} 4 \mathrm{f}$ doublet and $\mathrm{O} 1 \mathrm{~s}$ lines are presented in Fig. 5. Both Ir $4 \mathrm{f}_{7 / 2}$ and $4 \mathrm{f}_{5 / 2}$ lines are fitted to two components, Fig. 5a. The first component at lower binding energies consists of two peaks at $62.1 \mathrm{eV}$ and $64.9 \mathrm{eV}$ which according to the literature data ${ }^{30}$ correspond to iridium hydroxide, $\operatorname{Ir}(\mathrm{OH})_{3}$, but it can also be ascribed to $\mathrm{Ir}_{2} \mathrm{O}_{3} .{ }^{33}$ The second doublet at higher binding energies of $62.7 \mathrm{eV}$ and $65.6 \mathrm{eV}$ for $\mathrm{Ir} 4 \mathrm{f}_{7 / 2}$ and $4 \mathrm{f}_{5 / 2}$, respectively, correspond either to $\mathrm{IrCl}_{3}\left(62.5 \mathrm{eV}\right.$ and $65.4 \mathrm{eV}$ in Ref. 31), or to hydrated $\mathrm{IrCl}_{3}(62.6 \mathrm{eV}$ 


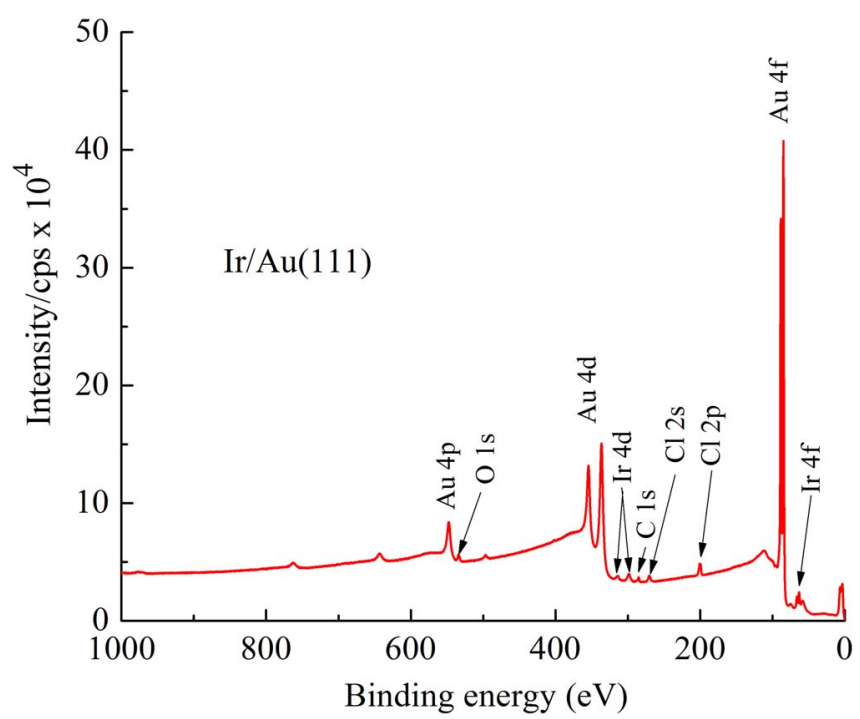

Figure 3. XPS spectra taken from $\mathrm{Ir} / \mathrm{Au}(111)$ showing the positions of the main components.
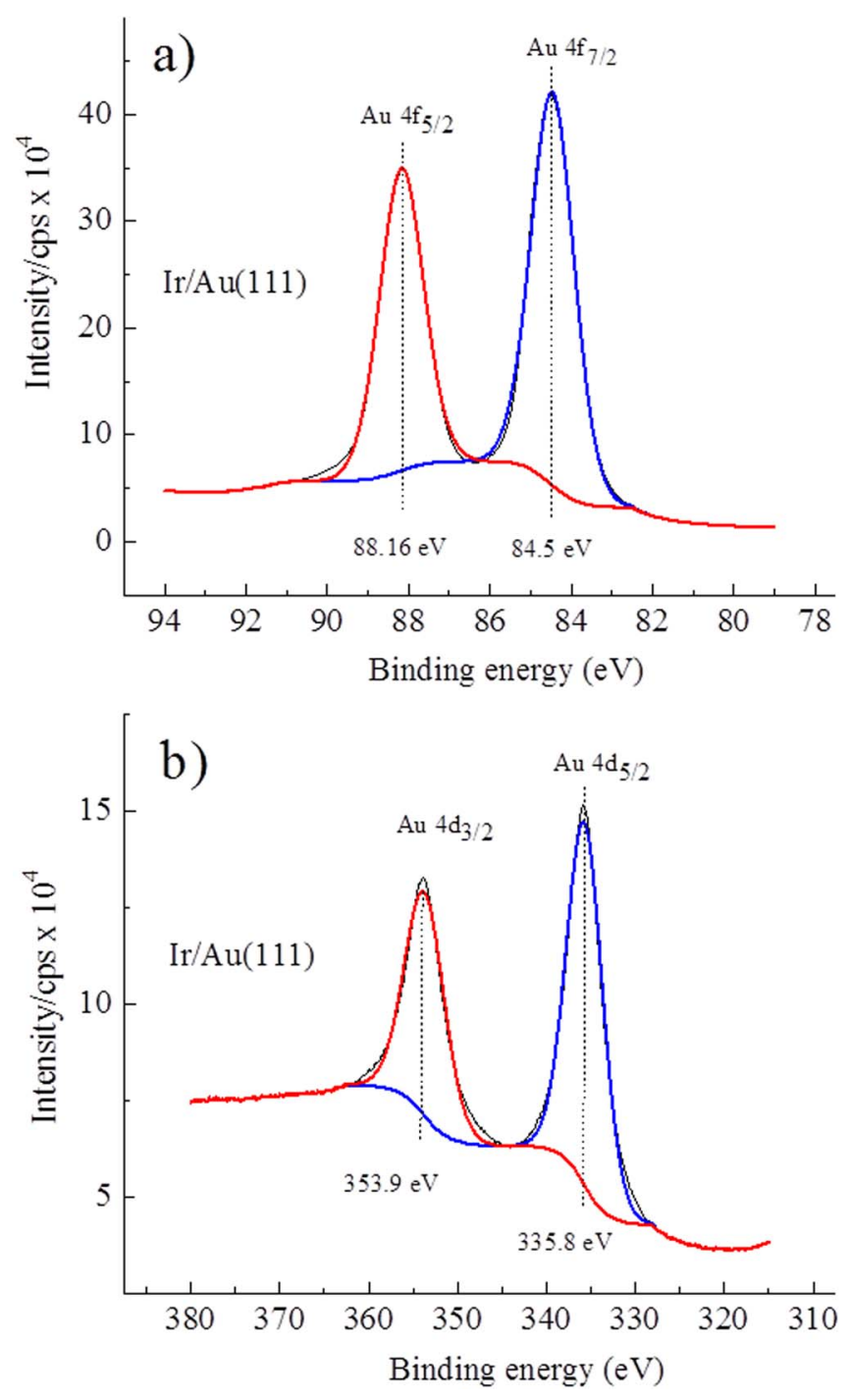

Figure 4. High resolution region XPS spectra taken from Ir/Au(111) showing the fitted binding energies of: a) Au 4f; b) Au 4d photoelectron lines.
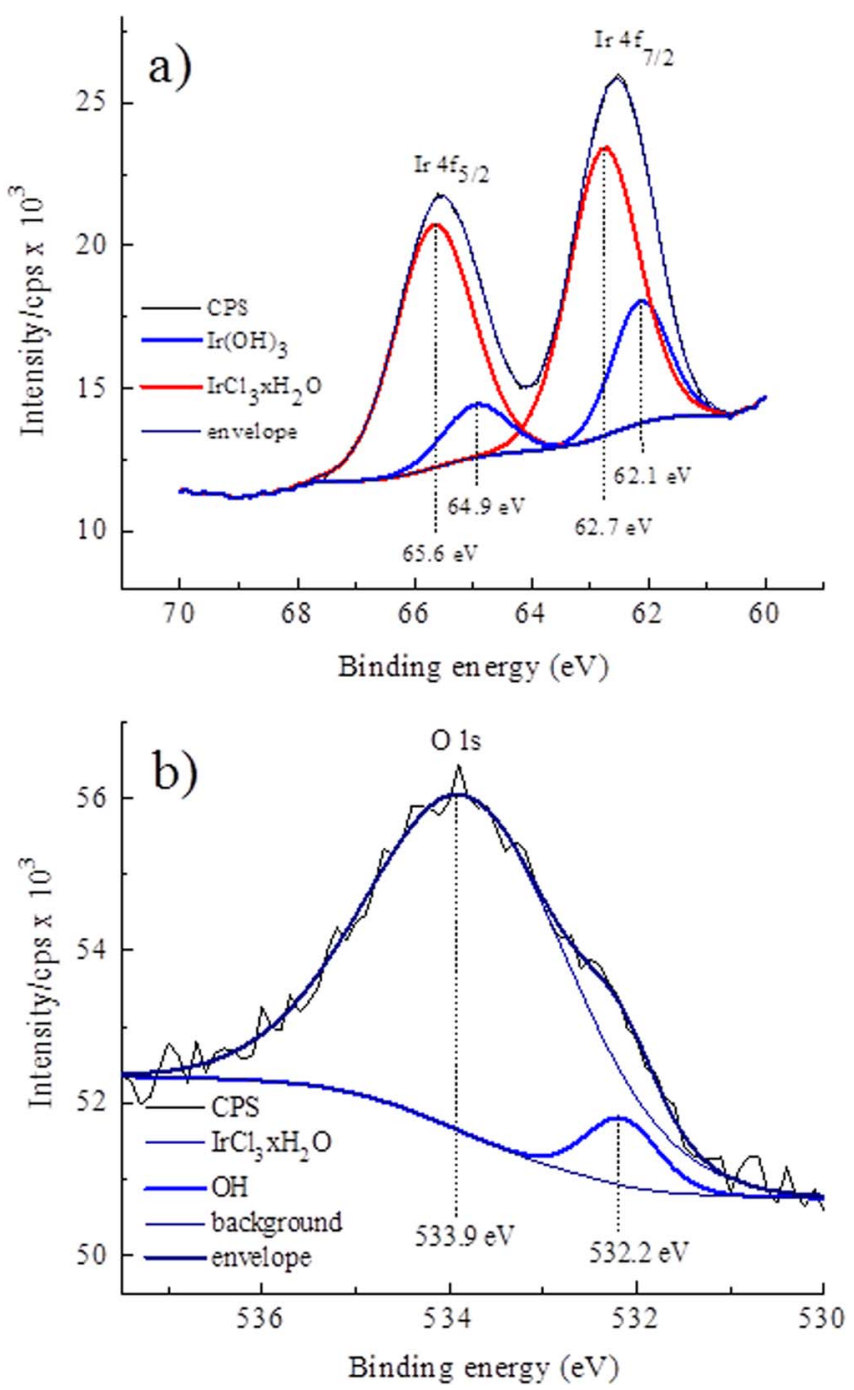

Figure 5. High resolution region spectra taken from $\operatorname{Ir} / \mathrm{Au}(111)$, showing the fitted binding energies of: a) Ir 4f; b) O 1s photoelectron lines.

and 65.6 in Ref. 32). It should be noted that based on the $4 f_{7 / 2}$ binding energies, there are no lines for metallic $\mathrm{Ir}^{0}$ and $\mathrm{Ir}^{4+}$, which should appear at $61.0 \mathrm{eV}$ and $63.7 \mathrm{eV}$, respectively). ${ }^{30,32,33}$

High resolution spectrum of $\mathrm{O} 1 \mathrm{~s}$ is fitted to two components, Fig. 5b. The first component at lower binding energy of $532.2 \mathrm{eV}$ can be ascribed to hydroxide species (531.5 eV in Ref. 30, and $532.0 \mathrm{eV}$ in Ref. 32), which confirms the presence of $\operatorname{Ir}(\mathrm{OH})_{3}$. The second component, at higher binding energy of $533.9 \mathrm{eV}$ can be ascribed to water (533.6 eV in Ref. 32), originating from adsorbed $\mathrm{IrCl}_{3} \cdot \mathrm{xH}_{2} \mathrm{O}$. There is no $\mathrm{O} 1 \mathrm{~s}$ peak at lower binding energies, which would correspond to oxygen from oxide (for $\mathrm{O}^{2-}$ in either $\mathrm{Ir}_{2} \mathrm{O}_{3}$ or $\mathrm{IrO}_{2}, \mathrm{O}$ 1s peak should be at $530 \mathrm{eV}$, Refs. 30 and 32).

Taking into account detailed analysis of the binding energies of Ir $4 \mathrm{f}$, and $\mathrm{O} 1 \mathrm{~s}$ peaks given above and their relative intensities, one can conclude that iridium deposit consists mainly of adsorbed hydrated $\mathrm{IrCl}_{3}$ and to a lesser extent of $\operatorname{Ir}(\mathrm{OH})_{3}$.

Cyclic voltammetry of $\mathrm{Ir} / \mathrm{Au}(111)$ surfaces.-Cyclic voltammograms of different Ir/Au(111) bimetallic electrodes, as well as bare $\mathrm{Au}(111)$ single crystal and $\operatorname{Ir}($ poly) wire recorded in the same potential limits from $-0.18 \mathrm{~V}$ up to $0.95 \mathrm{~V}$, are presented in Fig. 6. With repeating cycling, $\mathrm{CVs}$ of $\mathrm{Ir} / \mathrm{Au}(111)$ are reproducible, meaning that the obtained Ir deposit is stable. It can be seen that due to the presence of Ir nanoislands on the $\mathrm{Au}(111)$ substrate, all the peaks characteristic 


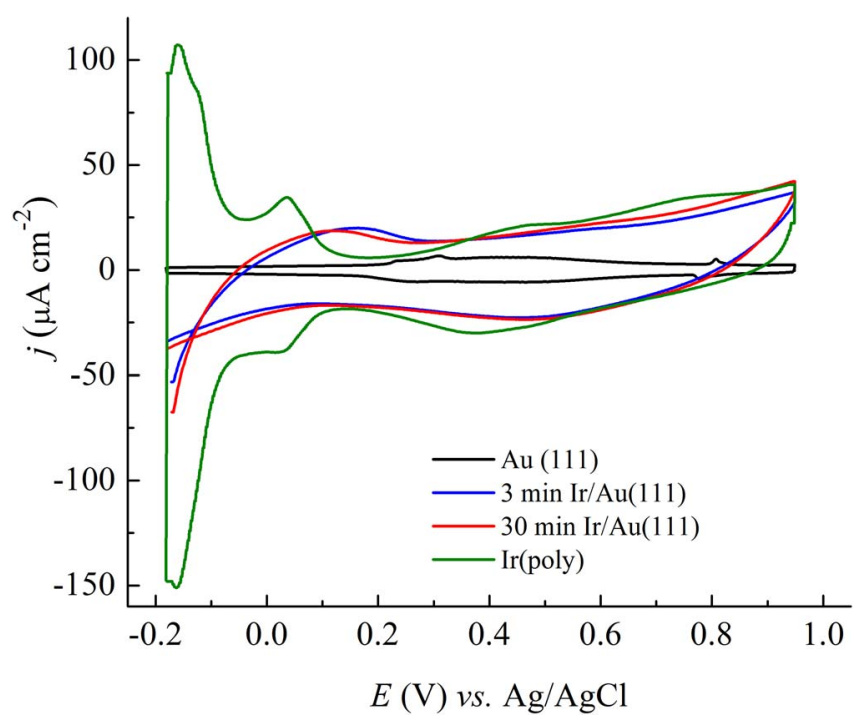

Figure 6. Cyclic voltammetry curves recorded in $0.5 \mathrm{M} \mathrm{H}_{2} \mathrm{SO}_{4}$ of $\mathrm{Ir} / \mathrm{Au}(111)$, bare $\mathrm{Au}(111)$ and $\mathrm{Ir}\left(\right.$ poly) electrodes. Scan rate was $50 \mathrm{mVs}^{-1}$.

for bare $\mathrm{Au}(111)$ single crystal such as surface reconstruction, lifting of the reconstruction and butterfly peaks at around $0.8 \mathrm{~V}^{34}$ disappear. According to the CV curve of bare $\operatorname{Ir}($ poly), which shows all typical features of polycrystalline iridium in sulfuric acid solution. ${ }^{25,35-37} \mathrm{Re}$ versible peaks for hydrogen adsorption/desorption which take place at lower potentials, are not clearly resolved on the CVs of $\mathrm{Ir} / \mathrm{Au}(111)$ electrodes. Instead, a broad peak is observed in that potential region, which cannot be ascribed only to hydrogen adsorption/desorption on Ir, but also to the presence of non-reducible Ir islands, most likely $\mathrm{Ir}_{2} \mathrm{O}_{3}$ according to Refs. 22 and 23. Namely, the absence of defined Hupd region means that the deposited Ir was not in the metallic state even after the deposit was stabilized by conditioning before CV was recorded. We suppose that a fraction of non-reducible Ir oxides on gold substrate is generated at lower potentials from tightly adsorbed both $\mathrm{IrCl}_{3} \mathrm{xH}_{2} \mathrm{O}$ and $\mathrm{Ir}(\mathrm{OH})_{3}$. Further study is needed to prove the formation and nature of non-reducible Ir oxides on gold from spontaneously deposited Ir species.

The oxidation of bare $\operatorname{Ir}($ poly) takes place at higher potentials, which can be seen through the increase of the current density starting at approx. $0.2 \mathrm{~V}$. According to Refs. 25,35-37, the oxidation of Ir starts with the adsorption of $\mathrm{OH}$ up to the formation of $\mathrm{IrOH}$ monolayer. This is than reduced in the backward scan showing reversible oxidation/reduction behavior up to the potential of approx. $0.5 \mathrm{~V}$. At higher potentials up to $0.95 \mathrm{~V}$, which is set as the positive potential limit, further oxidation involves the adsorption of both $\mathrm{OH}$ and $\mathrm{O}$, and Ir oxidation/reduction become irreversible reactions. This means that in the reverse scan the reduction of Ir oxide proceeds to the lower potentials and partially overlaps with hydrogen adsorption. On the other hand, the oxidation of Ir deposited on $\mathrm{Au}(111)$ starts at approx. $0.3 \mathrm{~V}$ and proceeds in a similar manner as the oxidation of bare Ir, although shifted toward more positive potentials. In the reverse scan, there is a wide reduction peak with a center at approx. $0.5 \mathrm{~V}$. Reduction of Ir oxide on $\mathrm{Ir} / \mathrm{Au}(111)$ takes place in the whole reverse scan down to the beginning of HER as in the case of Rh deposited on $\mathrm{Au}(111) .{ }^{11} \mathrm{It}$ is also noted that currents at CVs for bimetallic electrodes are much bigger than on bare $\mathrm{Au}(111)$ electrode, indicating the presence of nonreducable Ir oxides.

Usually electrochemically active surface area (ECSA) is determined either through evaluation of Hupd region in $\mathrm{CV}$ curves or through CO stripping curves. Unfortunately, in this case there is no defined Hupd potential region on CVs. There is also not a well defined $\mathrm{CO}$ oxidation peak for the obtained bimetallic $\mathrm{Ir} / \mathrm{Au}(111)$ surfaces. As a result of this, neither of these can be used for ECSA determination.
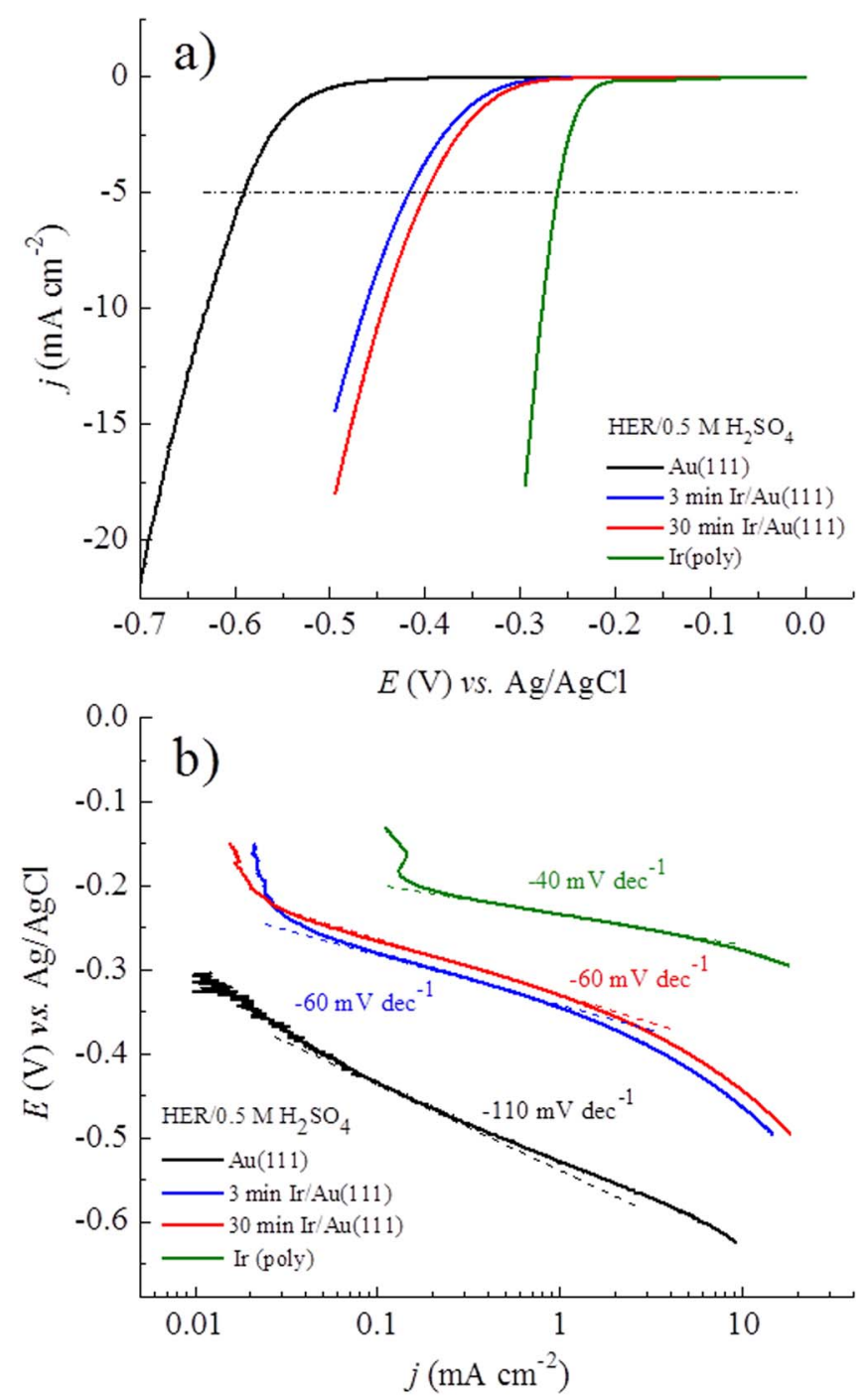

Figure 7. HER on $\operatorname{Ir} / \mathrm{Au}(111)$, bare $\mathrm{Au}(111)$ and $\operatorname{Ir}($ poly) electrodes: a) polarization curves recorded in $0.5 \mathrm{M} \mathrm{H}_{2} \mathrm{SO}_{4}$ recorded at a scan rate of $10 \mathrm{mV} / \mathrm{s}$; b) corresponding Tafel plots.

Hydrogen evolution reaction on Ir/Au(111) surfaces.-Polarization curves for HER on bare $\mathrm{Au}(111)$, different Ir/Au(111) electrodes and $\operatorname{Ir}$ (poly) recorded in $0.5 \mathrm{M} \mathrm{H}_{2} \mathrm{SO}_{4}$ solution are presented in Fig. $7 \mathrm{a}$. Difference in the HER activities between $\mathrm{Au}(111)$ and Ir is rather notable since the difference between the HER potentials at the same current density of $-5.0 \mathrm{~mA} \mathrm{~cm}{ }^{-2}$ is around $330 \mathrm{mV}$. Activities of the examined Ir/Au(111) electrodes for HER fall in between the ones for bare $\mathrm{Au}(111)$ and $\mathrm{Ir}($ poly). The difference between potentials for HER on $\mathrm{Au}(111)$ and $\mathrm{Ir} / \mathrm{Au}(111)$ obtained after 3 and 30 min deposition at the same current density is $170 \mathrm{mV}$, and $190 \mathrm{mV}$, respectively. According to the AFM images, the coverage obtained after 30 minutes was only slightly higher than that of $3 \mathrm{~min}$ deposition. However, the Ir islands obtained after $30 \mathrm{~min}$ deposition are wider, which probably causes the better catalytic activity for HER. If the deposition time is further prolonged to 60 minutes no significant change in the HER activity is obtained with respect to the deposition time of $30 \mathrm{~min}$, meaning that, the enhancement of the catalytic activity for HER of $\mathrm{Au}(111)$ electrode modified with spontaneously deposited Ir is limited. The activity of obtained Ir/Au(111) bimetallic surfaces for HER is limited also by the nature of the deposited Ir species. XPS data (see Fig. 5) have shown the presence of hydrated $\operatorname{IrCl}_{3}$ and $\operatorname{Ir}(\mathrm{OH})_{3}$, but no metallic Ir, and even after conditioning, CV curve (see Fig. 6) has shown no defined Hupd region meaning that the deposited Ir species 
are not reduced to $\mathrm{Ir}^{0}$. Therefore, the presence of non-reducible $\mathrm{Ir}$ species, even in the potential region of hydrogen evolution, limits the activity of $\mathrm{Ir} / \mathrm{Au}(111)$ eletrodes obtained by spontaneous deposition of Ir using $\mathrm{IrCl}_{3} \cdot \mathrm{xH}_{2} \mathrm{O}$ as the depositing salt.

Recorded polarization curves were reproducible enough, varying within the experimental error of $\pm 2 \mathrm{mV}$, even during repeating LV scans, which indicated that Ir deposit remained stable during HER.

In acid media, HER proceeds in two steps with adsorbed hydrogen as the only intermediate. In the first step, which is always Volmer reaction, the discharge of proton produces the adsorbed hydrogen as the intermediate,

$$
\mathrm{H}^{+}+\mathrm{e}^{-} \rightarrow \mathrm{H}_{\mathrm{ad}} \quad \text { Volmer }
$$

while in the second step molecular hydrogen is produced on the surface either through Tafel reaction, in which the recombination of two adsorbed hydrogen atoms takes place,

$$
\mathrm{H}_{\mathrm{ad}}+\mathrm{H}_{\mathrm{ad}} \rightarrow \mathrm{H}_{2} \quad \text { Tafel }
$$

or through Heyrovski reaction in which adsorbed hydrogen atom reacts with a second proton,

$$
\mathrm{H}^{+}+\mathrm{e}^{-}+\mathrm{H}_{\mathrm{ad}} \rightarrow \mathrm{H}_{2} \quad \text { Heyrovski }
$$

HER mechanism can be discussed through Tafel analysis of the corresponding polarization curves, as given in Fig. 7b. For the bare $\mathrm{Au}(111)$ electrode, Tafel slope of $-110 \mathrm{mV} \mathrm{dec}-1$ is obtained and assigned to Volmer-Heyrovsky mechanism. ${ }^{7,10}$ The slope of $-40 \mathrm{mV} \mathrm{dec}{ }^{-1}$ fitted for HER on $\operatorname{Ir}$ (poly) can be attributed to either Volmer-Tafel or Volmer-Heyrowsky mechanism under Temkin conditions similarly as for Rh(poly) in acid solution. ${ }^{38}$ Similar values for Tafel slopes are obtained for HER on carbon-supported $\mathrm{IrO}_{2}{ }^{19}$ and $\mathrm{IrO}_{\mathrm{x}} / \mathrm{Ti}$ electrodes. ${ }^{20}$ Tafel slope for bimetallic $\mathrm{Ir} / \mathrm{Au}(111)$ electrodes obtained after 3 and 30 min deposition is $-60 \mathrm{mV} \mathrm{dec}^{-1}$ and can be assigned to the Volmer-Tafel mechanism with the Tafel step as the rate determining, as it was reported for different $\mathrm{Rh} / \mathrm{Au}(111)$ nanostructures. ${ }^{10}$

The enhancement of the catalytic activity for HER of $\operatorname{Ir} / \mathrm{Au}(111)$ in $0.5 \mathrm{M} \mathrm{H}_{2} \mathrm{SO}_{4}$ with respect to bare $\mathrm{Au}(111)$ can be compared with the activities of $\mathrm{Pd} / \mathrm{Au}(111)^{7}$ and $\mathrm{Rh} / \mathrm{Au}(111)^{10}$ bimetallic electrodes, where both $\mathrm{Rh}$ and Pd were also spontaneously deposited on $\mathrm{Au}(111)$. It is important to point out that spontaneously deposited Ir improves the activity of gold significantly, but that its contribution is limited by both the morphology and the nature of the deposit, unlike in the case of $\mathrm{Rh}$, where the activity of $\mathrm{Rh} / \mathrm{Au}(111)$ approaches that of Pt. ${ }^{10}$

\section{Conclusions}

The results presented in this work have shown that under given depositing conditions, a full coverage of $\mathrm{Au}(111)$ surface with Ir is achieved after only $3 \mathrm{~min}$. After prolonged deposition, only the increase in lateral size of the deposited Ir islands has been observed, but not the increase in the deposit height. Such limited changes in the deposit morphology are reflected in the limited catalytic effect on HER in acid solution. Besides, the presence of non-reducible Ir species, even after conditioning, limits the activity of obtained $\mathrm{Ir} / \mathrm{Au}(111)$ electrodes for HER. Although pronounced catalysis of HER has been observed compared to bare $\mathrm{Au}(111)$, the activity of bimetallic $\mathrm{Ir} / \mathrm{Au}(111)$ surfaces has not reached the activity of bare $\operatorname{Ir}($ poly).

\section{Acknowledgment}

The work was supported by the Ministry of Education, Science and Technological Development, Republic of Serbia, project $N^{\circ} 45005$.

\section{ORCID}

Svetlana Štrbac (1D https://orcid.org/0000-0002-6081-0203

\section{References}

1. S. Trasatti, J. Electroanal. Chem., 39, 163 (1972)

2. P. Quaino, F. Juarez, E. Santos, and W. Schmickler, Beilstein J. Nanotechnol., 5846 (2014).

3. J. K. Nørskov, T. Bligaard, A. Logadottir, J. R. Kitchin, J. G. Chen, S. Pandelov, and U. Stimming, J. Electrochem. Soc, 152, J23 (2005)

4. L. A. Kibler, Chem. Phys. Chem., 7, 985 (2006).

5. S. Pandelov and U. Stimming, Electrochim. Acta, 52, 5548 (2007).

6. P. J. Schafer and L. A. Kibler, Phys. Chem. Chem. Phys., 12, 15225 (2010)

7. M. Smiljanić, I. Srejić, B. Grgur, Z. Rakočević, and S. Štrbac, Electrocatal., 3, 369 (2012).

8. E. Santos, P. Hindelang, P. Quaino, E. N. Shulz, G. Soldano, and W. Schmickler, ChemPhysChem, 12, 2274 (2011).

9. G. Soldano, E. N. Shulz, D. R. Salinas, E. Santos, and W. Schmickler, Phys. Chem. Chem. Phys., 13, 16437 (2011).

10. M. Smiljanić, I. Srejić, B. Grgur, Z. Rakočević, and S. Štrbac, Electrochem. Commun., 28, 37 (2013)

11. S. Štrbac, M. Smiljanić, and Z. Rakočević, J. Electrochem. Soc., 163, D3027 (2016).

12. Z. Rakočević, M. Smiljanić, and S. Štrbac, ECS Trans., 85, 185 (2018).

13. J. P. Hoare and S. Schuldiner, J. Chem. Phys., 25, 786 (1956).

14. A. Ganassin, P. Sebastián, V. Climent, W. Schuhmann, A. S. Bandarenka, and J. Feliu, Scientific Reports, 7, 1246 (2017).

15. B. Łosiewicz, R. Jurczakowski, and A. Lasia, Electrochim. Acta, 225, 160 (2017)

16. M. Angeles Montero, José L. Fernández, M. Rosa Gennero de Chialvo, and Abel C. Chialvo, J. Phys. Chem. C, 117, 25269 (2013).

17. J. Durst, C. Simon, F. Hasché, and H. A. Gasteiger, J. Electrochem. Soc., 162, F190 (2015).

18. X. Xu, X. Wang, S. Huo, Z. Chen, H. Zhao, and J. Xu, Catal. Today, (2017) http://dx.doi.org/10.1016/j.cattod.2017.09.054

19. J. Cheng, H. Zhang, H. Ma, H. Zhong, and Y. Zou, Electrochim. Acta, 55, 1855 (2010).

20. J. C. F. Boodts and S. Trassati, J. Appl. Electrochem., 19, 255 (1989).

21. L. D. Burke, N. S. Naser, and B. M. Ahern, J. Solid State Electrochem., 11, 655 (2007).

22. L. Vázquez-Gómez, S. Cattarin, P. Guerriero, and M. Musiani, Electrochim. Acta 53, $8310(2008)$

23. S. R. Mellsop, A. Gardiner, and A. T. Marshall, Electrocatal., 7, 226 (2016)

24. M. Duca, E. Guerrini, A. Colombo, and S. Trasatti, Electrocatal., 4, 338 (2013).

25. D. A. J. Rand and R. Woods, J. Electroanal. Chem. Interfacial Electrochem., 55, 375 (1974)

26. D. A. Fine, J. Inorg. Nucl. Chem., 32, 2731 (1970).

27. N. H. Turner and A. M. Single, Surf. Interface Anal., 15, 215 (1990).

28. P. Heimann and J. F. Van der Veen, Solid State Commun., 38, 595 (1981).

29. J. Jia, A. Bendounan, H. M. N. Kotresh, K. Chaouchi, F. Sirotti, S. Sampath, and V. A. Esaulov, J. Phys. Chem. C, 117, 9835 (2013).

30. S. Kato, J. Jung, T. Suenobu, and S. Fukuzumi, Energy Environ. Sci. 6, 3756 (2013).

31. B. D. El-Issa, A. Katrib, R. Ghodsian, B. A. Salsa, and S. H. Addassi, Int. J. Quantum Chem., 33, 195 (1988)

32. S. J. Freaklay, J. Ruiz-Esquius, and D. J. Morgan, Surf. Interface Anal. 49, 794 (2017).

33. M. Hara, K. Asami, K. Hashimoto, and T. Masumoto, Electrochim. Acta, 28, 1073 (1983).

34. A. Hamelin, J. Electroanal. Chem., 407, 1 (1996).

35. J. Mozota and B. E. Conway, Electrochim. Acta, 28, 1 (1983).

36. P. G. Pickup and V. I. Birss, J. Electroanal. Chem. 220, 83 (1987).

37. S. Cherevko, S. Geiger, O. Kasian, A. Mingers, and K. J. J. Mayrhofer, J. Electroanal Chem., 773, 69 (2016)

38. Z. Rakočević, M. Smiljanić, and S. Štrbac, ECS Transactions, 85, 185 (2018). 